\title{
SOBRE-SEMEADURA DE FORRAGEIRAS HIBERNAIS EM PASTAGEM DEGRADADA DE PENSACOLA COM DOSES DE GLIFOSATO
}

\author{
Francisco Antonio Marçallo \\ Orientador: Prof. Dr. Adelino Pelissari
}

\begin{abstract}
RESUMO
O presente trabalho foi conduzido na Fazenda Capão Redondo, situada no município de Candói - PR. Foi realizado nos anos agrícolas de 2000 e 2001, com o objetivo de avaliar a participação das forrageiras sobre-semeadas em pastagem degradada de pensacola, submetida à aplicação de glifosato, bem como o efeito desta aplicação no restabelecimento e na composição botânica da pastagem de pensacola. O delineamento experimental foi o de blocos ao acaso com seis tratamentos e duas repetições. Foram sobresemeados azevém, trevo branco, trevo vermelho e cornichão, após dessecação da pastagem de pensacola com doses de glifosato ( $\mathrm{T} 2=z e r o ; T 3=0,5 ; \mathrm{T} 4=0,75 ; \mathrm{T} 5=1,0 ; \mathrm{T} 6=1,25 \mathrm{~L}$.ha-1). A testemunha (T1) não recebeu herbicida, nem sobre-semeadura e adubo. Para a estimativa da participação de cada espécie na matéria seca disponível (MSd), foi utilizada a metodologia Botanal em quatro avaliações (08/12/00; 09/02/01; 06/06/01; 20/12/01). Observou-se que no tratamento sem herbicida houve excelente estabelecimento das forrageiras hibernais na época fria e restabelecimento da pensacola no verão. Concluiu-se que, nas condições em que este trabalho foi desenvolvido, não foi necessária a aplicação de glifosato para o estabelecimento das espécies em sobre-semeadura. A sobre-semeadura de espécies hibernais em pastagem naturalizada, com e sem a aplicação do herbicida glifosato, melhorou a qualidade da composição botânica da matéria seca disponível, mas influenciou negativamente a participação da pensacola no campo naturalizado. Observou-se também, que esta prática foi responsável pelo decréscimo das espécies naturais do campo, um ano após a sobre-semeadura. As diferentes dosagens de glifosato não influenciaram a participação das espécies sobre-semeadas, excetuando-se o trevo vermelho e o trevo branco, 8 meses e 18 meses após a sobre-semeadura, respectivamente. A pensacola sempre permaneceu inversamente proporcional à participação da espécies sobre-semeadas.
\end{abstract}

\begin{abstract}
A field study was conducted at Fazenda Capão Redondo, near Candói - PR in southern Brazil, to evaluate the practice of overseeding cool-season forages on a degraded pasture of pensacola (Paspalum notatum Flügge var. Saurae) with and without glyphosate application for sod suppression. The specific objectives were to evaluate the contribution of cool-season forages to the pasture and the effect of glyphosate application on subsequent regrowth and botanical composition of the pensacola pasture. The study was conducted during 2000 and 2001 using a randomized complete block design with six treatments and two replications. A seed mixture of annual ryegrass (Lolium multiflorum Lam.), white clover (Trifolium repens L.), red clover (Trifolium pratense L.), and birdsfoot trefoil (Lotus corniculatus $L$.) was oversown on the pensacola pasture after dessication with different rates of glyphosate $(T 2=0 ; T 3=0.5 ; T 4=0.75$; $\mathrm{T} 5=1.0 ; \mathrm{T} 6=1.25 \mathrm{~L} \mathrm{ha}^{-1}$ ). The control treatment (T1) was the original pasture without herbicide, fertilizer, or overseeding treatments. The Botanal method was used to estimate the presence of each species in the available dry matter on four dates (8-Dec-2000, 9-Feb-2001, 6-Jun-2001, 20-Dec-2001). In the treatment without glyphosate, excellent establishment of winter forages was observed during the cold months followed by regrowth of pensacola in the summer. In the occurrence of hoar the glyphosate application was not necessary for successful establishment of the oversown species. Overseeding cool-season species in naturalized pastures, with or without glyphosate application, increased the proportion of high quality forages in the available dry matter during the winter, but reduced the presence of pensacola in the naturalized pasture the following summer. This practice also decreased the presence of native species in the pasture one year after overseeding. Presence of pensacola was inversely proportional to the presence of oversown species.

Key-words: herbicide, naturalized pasture, Paspalum notatum, dessication, Botanal.
\end{abstract}

